\title{
Climate Change and Sea Ice: Local Observations from the Canadian Western Arctic
}

\author{
THERESA NICHOLS, ${ }^{1}$ FIKRET BERKES, ${ }^{2}$ DYANNA JOLLY,${ }^{3}$ NORMAN B. SNOW ${ }^{4}$ \\ and THE COMMUNITY OF SACHS HARBOUR ${ }^{5}$
}

\author{
(Received 16 September 2002; accepted in revised form 24 July 2003)
}

\begin{abstract}
Can local observations and indigenous knowledge be used to provide information that complements research on climate change? Using participatory research methodology and semi-directed interviews, we explored local and traditional knowledge about changes in sea ice in the area of Sachs Harbour, Northwest Territories. In this small Inuvialuit community, we interviewed all of the 16 community members and elders considered to be local experts on sea ice to ask about their observations. We organized their comments under the headings multiyear ice, first-year ice, fractures and pressure ridges, breakup and freezeup seasons, and other climate-related variables that influence sea ice (such as changes in winter, spring and summer temperatures, wind, rain, and thunderstorms). Observations were remarkably consistent in providing evidence of local change in such variables as multiyear ice distribution, first-year ice thickness, and ice breakup dates. The changes observed in the 1990s were said to be without precedent and outside the normal range of variation. In assessing the relevance of Inuvialuit knowledge to scientific research on climate change, we note some of the areas in which sharing of information between the two systems of knowledge may be mutually beneficial. These include the analysis of options for adapting to climate change and the generation of research questions and hypotheses for future studies.
\end{abstract}

Key words: Western Arctic, climate change, Inuvialuit, traditional ecological knowledge, sea ice

RÉSUMÉ. Est-ce que les observations locales et le savoir des Autochtones peuvent aider à fournir de l'information complétant la recherche sur le changement climatique? En faisant appel à une méthodologie de recherche participative et des entrevues semidirigées, on a examiné le savoir local et traditionnel concernant les changements de la banquise dans la région de Sachs Harbour (Territoires du Nord-Ouest). Dans cette petite communauté inuvialuite, on a interviewé les 16 membres et aînés de la communauté considérés comme des experts locaux de la banquise pour les interroger sur leurs observations. On a organisé leurs commentaires sous les rubriques suivantes: glace pluriannuelle, glace de l'année, crêtes de fractures et de pression, saisons de débâcle et d'engel, ainsi que d'autres variables reliées au climat qui influencent la banquise (comme les changements dans les températures hivernale, printanière et estivale, le vent, la pluie et les orages). Il y avait une concordance frappante dans les observations quant aux preuves de changements à l'échelle locale dans des variables comme la distribution de la glace pluriannuelle, l'épaisseur de la glace de l'année et les dates de la débâcle. Les changements observés au cours des années 1990 étaient, selon les Autochtones, sans précédent et ils dépassaient la gamme normale des variations. En évaluant la pertinence du savoir des Inuvialuits pour la recherche scientifique sur le changement climatique, on souligne certains des domaines dans lesquels le partage de l'information entre les deux systèmes de savoir pourrait être mutuellement profitable. Ces domaines comprennent l'analyse des options visant l'adaptation au changement climatique et la formulation de questions et hypothèses de recherche pour des études ultérieures.

Mots clés: Arctique de l'Ouest, changement climatique, Inuvialuit, savoir écologique traditionnel, banquise

Traduit pour la revue Arctic par Nésida Loyer.

\section{INTRODUCTION}

The issue of global climate change remains a topic of concern as greenhouse gases continue to accumulate in the atmosphere. Global climate models developed to investigate the consequences of rising carbon dioxide and methane levels continue to project temperature increases at the Earth's surface. However, increases in mean annual temperature will not be distributed equally around the globe. Instead, the largest average temperature increases are indicated over the polar regions (IPCC, 1995; Maxwell, 1997; Harvey, 2000), and already there is evidence that the polar ice cover is both thinning and shrinking in areal extent (Maslanik et al., 1999; Rothrock et al., 1999). However, the patterns of change are likely to be complicated by various regional and seasonal processes, such as Arctic

\footnotetext{
${ }^{1}$ Fisheries and Oceans Canada, 7646 - 8th Street NE, Calgary, Alberta T2E 8X4, Canada; Nicholstk@dfo-mpo.gc.ca

${ }^{2}$ Natural Resources Institute, University of Manitoba, 70 Dysart Road, Winnipeg, Manitoba R3T 2N2, Canada; Berkes@ cc.umanitoba.ca

${ }^{3}$ Centre for Maori and Indigenous Planning and Development, P.O. Box 84, Lincoln University, Canterbury, New Zealand

${ }^{4}$ Joint Secretariat-Inuvialuit Renewable Resources Committees, Box 2120, Inuvik, Northwest Territories X0E 0T0, Canada

${ }^{5}$ The Community of Sachs Harbour, c/o the Sachs Harbour Hunters and Trappers Committee, Sachs Harbour, Northwest Territories XOE 0Z0, Canada

(C) The Arctic Institute of North America
} 
oscillations, jet stream patterns, and ocean-atmospheric variables, and influenced by regional anthropogenic activities such as changes in land use and industrial practices.

The inherent limitations of the numeric climate models cause uncertainty to increase several-fold at finer scales (LeDrew and Barber, 1993). Projected changes to climate elements such as precipitation, winds, and ocean currents remain poorly understood, although their role in any climate change scenario will be considerable (IPCC, 1998). While the scientific community generally agrees upon the evidence for air temperature increases, great uncertainty remains regarding the overall nature of climate change and its impact on the environment (IPCC, 1998). Key questions remain regarding the resistance, resilience, and adaptation potential of natural and human systems to changing environmental conditions (IPCC, 1996; Berkes and Jolly, 2001).

Climate change, with its multitude of uncertainties, does not lend itself to analysis by conventional approaches. It falls into the class of problems that Ludwig (2001:759) calls "wicked problems" - those with "no definitive formulation, no stopping rule, and no test for a solution," problems that cannot be separated from issues of values, equity, and social justice. A future science of sustainability to replace conventional approaches to science and management must be created through a process by which researchers and local stakeholders interact to define important questions, relevant evidence, and convincing forms of argument (Friibergh Workshop, 2000). This kind of work requires participatory research and place-based models because understanding the dynamic interaction between nature and society requires case studies situated in particular places and cultures (Friibergh Workshop, 2000).

In the Arctic, place-based research may involve using indigenous observations and perspectives as an alternative way to monitor and understand climate change. Until recently, the majority of climate studies in the Arctic had excluded local knowledge, probably because scientists did not consider indigenous knowledge to be particularly relevant or accessible. This has been changing, as witnessed by the volume The Earth Is Faster Now, which contains nine chapters of indigenous observations of Arctic environmental change (Krupnik and Jolly, 2002). A growing number of studies have taken account of indigenous perspectives in the study of climate and other environmental change and the associated sociocultural impacts (McDonald et al., 1997; Fast and Berkes, 1998; Ingold and Kurttila, 2000; Berkes and Jolly, 2001; Cruikshank, 2001; Fenge, 2001; Riedlinger and Berkes, 2001). At least three cases have dealt specifically with indigenous observations of sea ice (Huntington, 2000; Krupnik, 2002; Norton, 2002), the subject of the present paper.

Why seek indigenous observations and knowledge of sea ice? Before the availability of remote sensing technologies, data on sea ice and Arctic climate were irregular and inconsistent. Data collection took place primarily on an opportunistic basis, typically onboard icebreakers, naval tankers, cargo ships and other vessels, or from coastal vantage points. Data were limited to consolidation dates, ice types, ice features, ice concentration, and in some cases, ice thickness. The advent of satellite remote sensing has made large-scale sea ice studies possible. However, climate data remain limited both temporally (no continuous records have been kept in the Arctic for much of the past 200 years) and spatially (there are few weather stations in the North). While satellite data have greatly augmented the earth's climate record, no comprehensive satellite data exist for comparison to years before the 1970s.

Given these knowledge gaps, local observations and traditional knowledge become significant, not as a replacement for science but as complementary information (Riedlinger and Berkes, 2001). For our purposes, traditional knowledge is defined as "a cumulative body of knowledge, practice and belief, evolving by adaptive processes and handed down through generations by cultural transmission" (Berkes, 1999:8). Traditional (or indigenous) knowledge is often passed between generations through oral history, stories, myths, song, and lessons, and more recently, in written form. Traditional knowledge is dynamic: it is modified by its holders to reflect changes in the environment as each new generation incorporates its own empirical knowledge or local observations.

For the indigenous people of the Arctic, the understanding of sea ice has always been necessary for survival. Sea ice provided, and continues to provide, a platform on which to travel, hunt, and fish (Freeman, 1984). Being able to identify and assess the type, composition, thickness, density, and strength of the ice is necessary to assess safety and ensure hunting success. People need to assess what types of equipment can traverse an area, at what speed, and in what direction, and to know the locations of ice-generated obstacles (Riewe, 1991; Norton, 2002). Understanding the relationships of sea ice to Arctic marine mammals and fish is also required (Freeman, 1984). For example, Inuit hunters know that ringed seals (Phoca hispida) excavate breathing holes through first-year sea ice and continue to make use of these holes throughout the winter (Smith and Stirling, 1975; Furgal et al., 1996). Hunters are also keenly aware that ringed seals exploit snowdrifts along the lee and windward slopes of pressure ridges, where they excavate subnivean lairs for birthing and weaning pups (Smith and Stirling, 1975; Nichols, 1999). As hunting and fishing activities remain important elements of Inuit cultural identity, such detailed knowledge is retained (Borre, 1991; Condon et al., 1995).

This paper focuses on the traditional and local knowledge held by Inuvialuit of Sachs Harbour in the Western Canadian Arctic. The study was carried out as part of the Inuit Observations of Climate Change (IOCC) project. Following a description of the IOCC project and the methods used in the study, we document knowledge about various aspects of sea ice: multiyear ice, first-year ice, fractures and pressure ridges, and breakup and freeze-up seasons, as well as observations on climate-related variables that influence sea ice, such as winter, spring, and 
summer air temperatures, wind, rain, and thunderstorms. Finally, we assess the relevance of Inuvialuit local and traditional knowledge to scientific research on climate change, highlighting areas in which sharing information between the two systems of knowledge may be mutually beneficial.

\section{METHODS}

The IOCC project was conducted in Sachs Harbour, Northwest Territories $\left(72^{\circ} \mathrm{N}, 125^{\circ} \mathrm{W}\right)$, located on the southern end of Banks Island in Canada's western Arctic (Fig. 1). The Inuvialuit are descendants of the Inupiat of Alaska, people of the Mackenzie Delta and the central Canadian Arctic. Sachs Harbour, with some 30 households, is the smallest of the six communities in the Inuvialuit Settlement Region formed under the Inuvialuit Final Agreement of 1984. Originally an outgrowth of the white fox trade that began in the 1920s, Sachs Harbour has been a permanent settlement since 1956 (Usher, 1970, 2002; Jolly et al., 2002).

In the 1990s, the people of Sachs Harbour became concerned that environmental changes in their area were making hunting difficult and creating safety problems. In 1998 , the community invited the International Institute for Sustainable Development (IISD) to produce a video to document local observations of climate change. The invitation was extended through Rosemary Kuptana, a community member, who was also on the Board of the IISD. The intent of the project was to educate southern Canadians and policy makers and to explore the potential contributions of Inuvialuit knowledge to climate change research.

From the outset, the IOCC project sought to establish a research partnership with the Sachs Harbour people, using methodology involving local participation to guide the study and ensure the full commitment of the community (Jolly et al., 2002). The key features of the project design included a planning workshop, repeat visits to document observations of climate change in all seasons, a thematic focus for each visit (sea ice, wildlife, permafrost) to allow local experts and scientists to interact directly, a university researcher to follow up on each visit, the use of a variety of feedback and communication tools, and a final workshop and verification. The project team included the IISD project director and facilitator, a film crew, local experts and liaison people from the Inuvialuit Settlement Region, a group of research scientists, and a university group, with the Sachs Harbour Hunters and Trappers Committee serving as the advisory group for the community.

The project began in 1999, with a collaborative planning workshop to establish joint objectives, define the scope of the study, and identify key issues from the community point of view to guide the work (Ford, 2000). The project team made three more trips to the community between June 1999 and May 2000 and a follow-up visit to conduct a final workshop and evaluation in 2001. For the

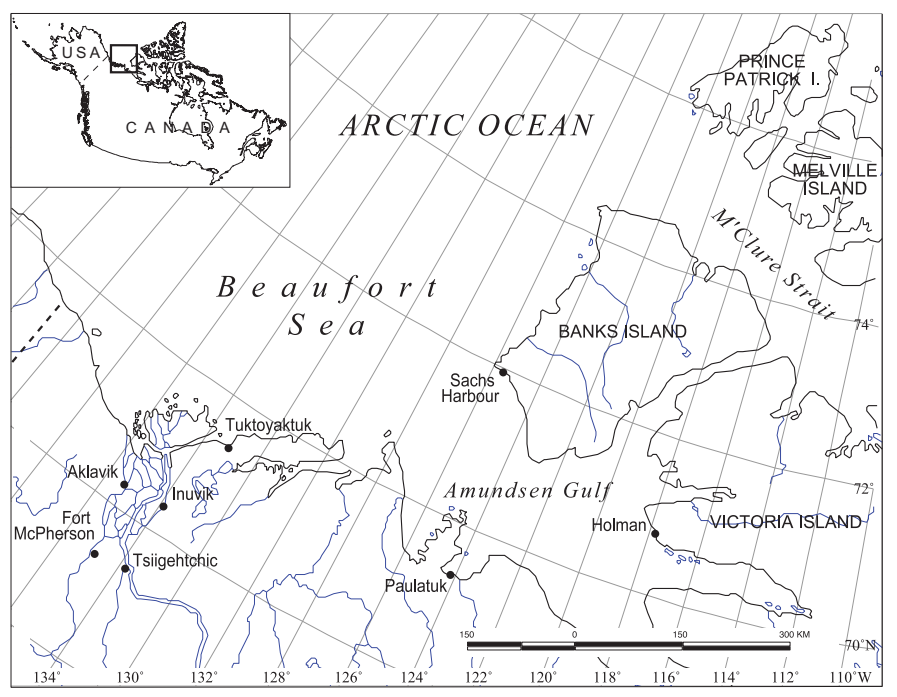

FIG. 1. The study area: Sachs Harbour on Banks Island, Northwest Territories.

thematic focus areas of the project, several scientists and researchers were recruited to help document traditional and local knowledge regarding the effects of climate change on sea ice, wildlife, and permafrost. This documentation occurred simultaneously with the video work. In November 2000, the production "Sila Alangotok: Inuit Observations on Climate Change" was simultaneously launched at the Sixth Conference of the Parties to the United Nations Framework Convention on Climate Change, held in The Hague, Netherlands; at a media conference in Ottawa; and in the community of Sachs Harbour.

One of the objectives of the planning workshop was to identify community priorities regarding climate change. Change in sea ice was identified as a top priority and the first thematic research area. The workshop identified a series of concerns and observations related to sea ice, which were used as a starting point for the detailed individual interviews. We invited all 16 elders and community members who had been identified by the community as experts on sea ice to share their observations and knowledge.

Using the semi-directed interview approach (Huntington, 1998), we conducted interviews over two weeks in September 1999. In the first week, eight interviews were conducted with one to two respondents at a time. Two researchers were present to guide the discussions, and a third researcher recorded the responses. In the second week, a single researcher interviewed four of the remaining respondents. The third researcher, who remained with the residents of Sachs Harbour for several weeks after the June 1999 planning meeting and returned on all three subsequent research trips, collected comments from one more respondent, as well as additional input from the original respondents, during subsequent visits to the community.

Interviews were casual and conducted in the homes of the respondents. All interviews were conducted in English, and only one respondent required an interpreter. The 
TABLE 1. The interview guide.

\begin{tabular}{|c|c|}
\hline Themes & Follow-up questions \\
\hline Multiyear ice & $\begin{array}{l}\text { Changes in abundance of multiyear ice? } \\
\text { Has there always been multiyear ice every year (in the harbour)? } \\
\text { Are there years when multiyear ice has not appeared? }\end{array}$ \\
\hline First year ice and ice features & $\begin{array}{l}\text { Is the pack ice moving? Is it farther away/closer to shore? Is it smaller (is there less) in the summer? } \\
\text { Where do pressure ridges normally form? } \\
\text { Are there changes in pressure ridges (location, shape, size)? } \\
\text { What direction (orientation) do they normally take? }\end{array}$ \\
\hline Seasons & $\begin{array}{l}\text { Changes in breakup dates? } \\
\text { Changes in consolidation (freeze-up) dates? } \\
\text { When do these seasons normally occur? } \\
\text { How do you define your seasons? By ice movement, by harvesting, or by animal migrations? How many seasons? }\end{array}$ \\
\hline Hunting and ice travel & $\begin{array}{l}\text { What are ideal conditions for seal hunting? } \\
\text { Where and how do you hunt and travel across the ice? } \\
\text { Has the timing of the hunt changed? } \\
\text { If so, how else has the hunt changed? }\end{array}$ \\
\hline Winds and storm events & $\begin{array}{l}\text { How often does it storm? } \\
\text { Is hail new to the community? } \\
\text { Are rainstorms more or less common? Are they more or less severe? Do they last a long time? } \\
\text { Have wind patterns changed? } \\
\text { Are winds becoming stronger or weaker? When do these events normally occur? }\end{array}$ \\
\hline
\end{tabular}

interview guide, developed as a follow-up to sea ice and climate issues raised in the original working group, is provided in Table 1. Each interview began with openended questions, using the interview guide as a starting place. Some of the questions were raised for clarification, to ensure that both parties were clear on definitions and understanding. Issues were followed up when the respondent was found to be knowledgeable and interested in particular issues. With their permission, all but two of the respondents were recorded on tape.

After the interviews, a trip report with summaries of the interviews was distributed to the community for verification. These notes were produced to ensure that respondents were correctly cited and that the community was satisfied that comments were not taken out of context or misinterpreted.

\section{RESULTS}

The working group identified several critical concerns related to changes in sea ice: diminishing amounts of multiyear ice, the increasing distance from shore of the multiyear ice, possible changes to pressure ridge abundance, sea ice thinning, and marked changes in the seasonal timing of sea ice breakup and freeze-up. These issues were selected as the focus for the interviews and served as the basis for the interview guide (Table 1). The consensus view of the respondents regarding the consequences of sea ice changes is illustrated in Figure 2 (fall-winter) and Figure 3 (spring-summer), which show that the Inuvialuit focus on relationships of a number of variables. Details of the observations by season and by subject area are summarized below. All the quotations were collected in Sachs Harbour during the field trips in 1999, except where noted otherwise.

\section{Multiyear Ice}

Multiyear ice is defined as ice that has survived a minimum of two summer melt seasons. Above the waterline, the freeboard layer of multiyear ice is characterized by nearly pure freshwater ice, having expelled its saline content through brine drainage. Other characteristics include thicknesses greater than $3 \mathrm{~m}$; smooth, rounded surface features; and a blue hue (see WMO, 1970). Multiyear ice floes offshore of Sachs Harbour have been a common sight throughout most of the year. Locally, these floes are also known as the Permanent Polar Pack Ice.

All Sachs Harbour respondents familiar with the multiyear ice unanimously agreed that its extent had decreased significantly in recent years (Table 2). Furthermore, there was consistent agreement that the multiyear ice edge was farther offshore. Nearly half of the respondents commented directly on the disappearance of the multiyear ice from view by (or before) July. One respondent reported that a few years earlier, he had observed very little multiyear ice at all during air travel to Inuvik; instead, only first-year ice was evident. Most respondents remarked that the change to the multiyear ice pack had been very abrupt over the previous two to three years, and that melt of the multiyear ice was occurring earlier and more quickly. Only one respondent believed the reduction in multiyear ice was part of a longer-term trend.

Seems like it is melting every year. Not like before. Before there would be at least [multiyear] ice... during the fall. Now there is no more.

Joe Kudlak, Sachs Harbour, 2000

We are not getting multiyear ice more often, like we used to. It is all freshly frozen snow that we are hunting on now. John Lucas, Sr. 


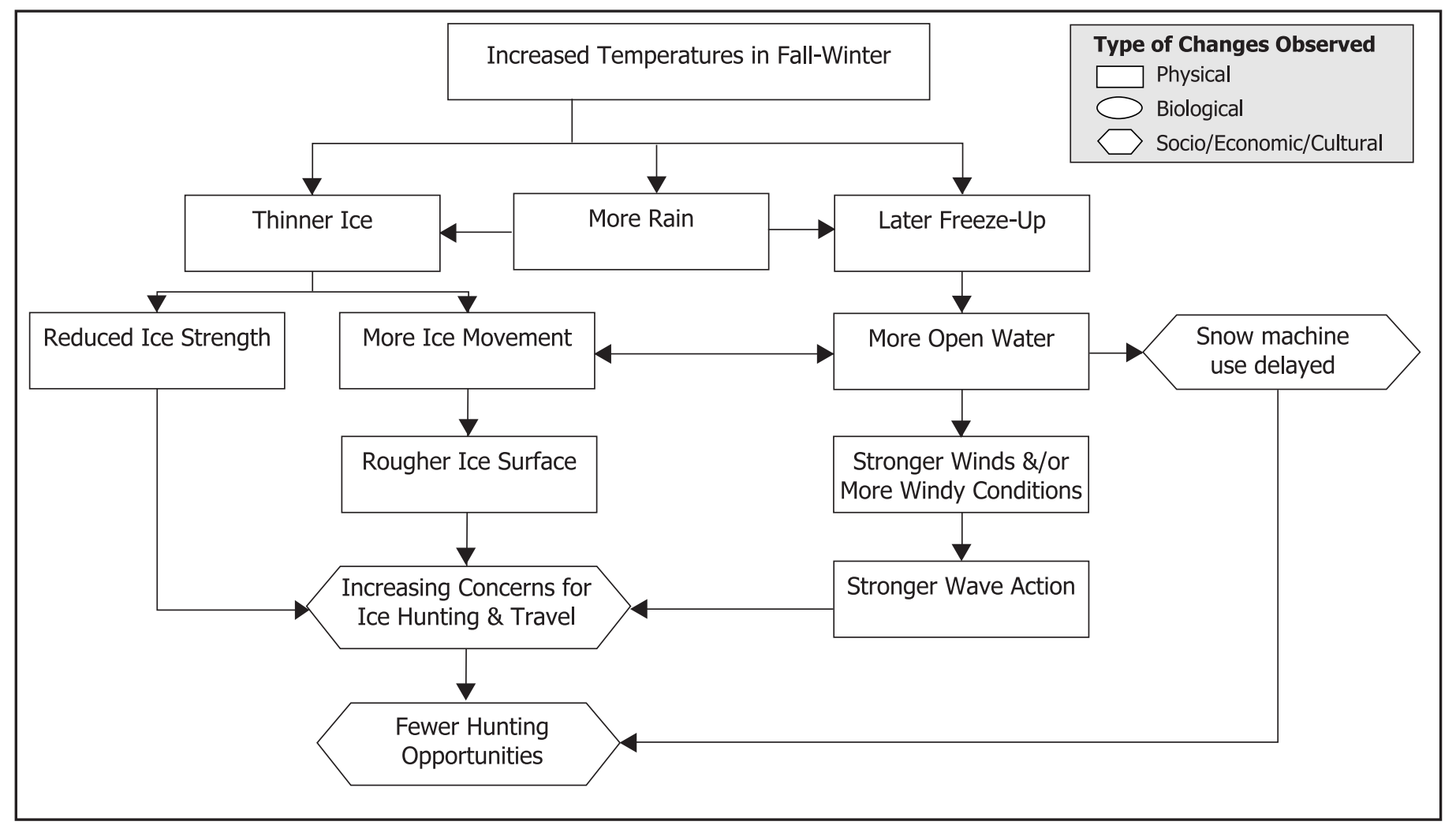

FIG. 2. Seasonal changes in sea ice and associated relationships, as observed by the Inuit of Sachs Harbour: fall and winter.

\section{First-Year Sea Ice Abundance and Ice Thickness}

First-year sea ice is the ice that forms annually and comprises the majority of the regional icescape. It is composed of freshwater ice, brine, and air, although the ratio varies over the season. First-year sea ice ranges from barely cohesive surface ice crystals to first-year ice types that are more than $1.2 \mathrm{~m}$ thick (WMO, 1970).

The respondents were unanimous in their assessment that there was less first-year ice annually and that the maximum thickness of the first-year ice was significantly less than in previous decades (Table 2). This assessment was frequently linked to the elements of ice safety and travel. One elder, renowned in the community for his expertise and intimate knowledge of sea ice, estimated average first-year sea ice thickness over previous decades to have been more than $2.5 \mathrm{~m}$, significantly thicker than in recent years. A second respondent estimated a $30 \mathrm{~cm}$ reduction in the sea ice thickness over recent years.

A third elder/hunter provided the background on how Inuit are able to detect visually and evaluate sea ice thickness. He outlined how ice thickness, ice age, and ultimately ice safety are determined from ice texture and colour. Hunters use this information to identify areas of thin ice, as well as areas where ice has previously broken and refrozen. Such information is valuable for safety, travel, and selecting good hunting locations. Using this knowledge during recent air travel, he concluded that thin ice makes up a greater portion of the total ice than it used to. Many of the other hunters echoed the growing concerns over thin ice and its effect on ice safety. "You have to really watch when you travel on the ice, you need to have experience...you have to know the condition." Many of the respondents pointedly remarked that this type of safety concern did not exist previously.

Even just up to a few years ago, we used to be able to go out with dogsleds with hunters-maybe five or six years ago, we used to be able to go quite a ways and not worry about it. The last three years or so, the last two anyway...12 miles is the limit.

Larry Carpenter

\section{Fractures and Pressure Ridges}

Fracture is a general term for cracks in the sea ice. Fractures are typically the result of tides, temperature changes, currents, and wind. The length of fractures varies from a few metres to several kilometres. Various types of fractures exist, including cracks, leads, flaws, and polynyas. Fractures are unstable features and can be quickly refrozen under calm cold temperatures, or can be compressed together under sufficient winds or currents to create pressure ridges. Both fractures and ridges are characteristic of the icescape near Sachs Harbour, and they are important factors in the biological success of several Arctic marine species (Nichols, 1999). These features play a significant role in determining hunting locations, travel routes, and hunter safety. 
TABLE 2. Present abundance and distribution of multiyear and first-year sea ice compared to ice of previous decades, according to local experts in Sachs Harbour, Northwest Territories. ${ }^{1}$

\begin{tabular}{|c|c|c|c|c|}
\hline Respondent & Multiyear abundance & Multiyear distribution & First-year ice thickness & Overall ice abundance \\
\hline A & & Further out & Thinner & Less \\
\hline B & & Further out & Thinner & Less \\
\hline $\mathrm{C}$ & Less & Further out & Thinner & Less \\
\hline $\mathrm{D}$ & Less & Further out & Thinner & Less \\
\hline $\mathrm{E}$ & Less & & Thinner & Less \\
\hline $\mathrm{F}$ & Less & Further out & Thinner & \\
\hline \multicolumn{5}{|c|}{ ค } \\
\hline $\mathrm{H}$ & Less & Further out & Thinner & \\
\hline I & Less & Further out & Thinner & Less \\
\hline $\mathrm{J}$ & Less & Further out & Thinner & Less \\
\hline $\mathrm{K}$ & Less & Further out & Thinner & Less \\
\hline $\mathrm{L}$ & Less & Further out & Thinner & Less \\
\hline M & Less & Further out & & Less \\
\hline $\mathrm{N}$ & Less & Further out & Thinner & Less \\
\hline $\mathrm{O}$ & Less & Further out & Thinner & Less \\
\hline $\mathrm{P}$ & Less & & Thinner & Less \\
\hline
\end{tabular}

${ }^{1}$ Blank box indicates no information available.

For most of Sachs Harbour's settlement history, cracks have been considered common features within the harbour; however, several respondents expressed the belief that the abundance of fractures had declined during the past decade and suggested that stronger winds may have been responsible for closing the nearshore openings. Other references to the fractures were more generally linked to the breakup season.

Used to be [tidal cracks] right up here close. No moreprobably because of wind.

$$
\text { Larry Carpenter }
$$

Only half of the respondents commented on the pressure ridges, and the majority of those did not express concern that pressure ridges in the area had undergone observable changes in either abundance or distribution. Two elders, on separate occasions, explained that the currents, not the winds, were responsible for pressure ridge creation, and that the currents remained unchanged.

\section{Breakup Season}

Overall, respondents unanimously agreed that breakup was occurring earlier now than in previous decades (Table 3). The majority also observed that breakup was occurring at a significantly faster rate. Since the 1950s, breakup in Sachs Harbour had typically occurred in late June to early July. In recent years, the onset of breakup was reported to have occurred several weeks earlier, in midJune. Respondents commented that for much of Sachs Harbour's history, breakup had rarely been complete before the ice began to refreeze, and that ice in the harbour was common all summer. A number of respondents recalled several Septembers after settlement when the dogs ran alongside the boats. Barges often had trouble entering the harbour, and the Inuvialuit would use their own schooners. The timing and arrival of the barges was watched closely, as it related directly to the arrival of various goods and supplies. The years 1967 (the Canadian Centennial Year) and 1979 were identified as prominent years when the community remained on the ice throughout the summer. Years with no ice breakup were not the norm, but they did occur in the past.

[It] used to open up in July long ago. Now, it opens up right away - the first part of June. Long ago when people stay[ed] at the Blue Fox [in Lennie Harbour], the ice never melt[ed] all summer so they couldn't get across. Tough to get groceries. You couldn't go with a schooner.

Lena Wolki

It goes out quicker now...It is different.

Edith Haogak and Sarah Kuptana

The presence of ice was related to higher numbers of ringed seals in the area and a higher survival rate for the seal pups born in late March and early April. The high concentration of ringed seals in the harbour attracts polar bears (Ursus maritimus). Several lifelong hunters commented that in earlier years, they had frequently witnessed polar bears on the ice offshore even during the summer and fall, but the bears did not normally venture onto land. However, in recent years the open water has caused the bears to move either onto land or farther offshore. During the 1990s, at least two bears entered the community.

The effects of the early melt and lack of ice in the harbour were linked by several elders to the biological responses exhibited by the ringed seal and the polar bear. From the scientific perspective, ringed seals are characterized as "pagophilic" or ice-loving. From the hunter's perspective, the combination of ice floes, high numbers of seals, and calm, safe boating conditions during the breakup season results in successful seal hunts. Polar bears are 


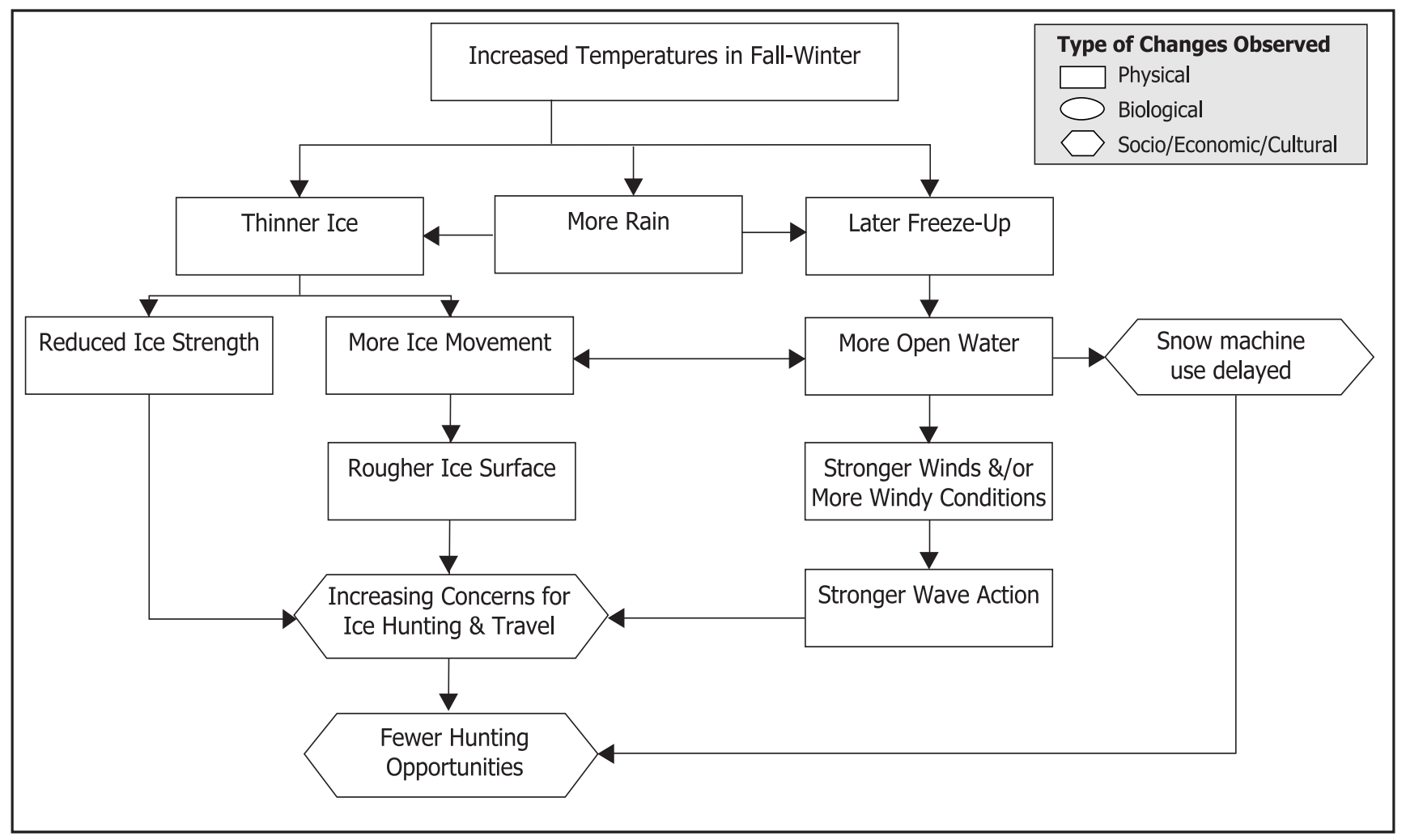

FIG. 3. Seasonal changes in sea ice and associated relationships, as observed by the Inuit of Sachs Harbour: spring and summer.

drawn to the area by abundant prey, increasing the opportunities to conduct polar bear hunts. In sharp contrast, the reduction in ice during spring throughout the 1990s was identified as having the opposite effect: fewer seals in the area, rougher waters, and dangerous boating conditions. Under such conditions, hunters are limited to the nearshore area, while the seals move farther offshore. These conditions also restrict the hunt for polar bears, with an adverse effect on the local economy.

Well now, when you are sport hunting, you can really notice it now. All the bears are further out; they are not closer. I don't know if it could be from too much traffic close by the beach or that sort of thing, but from what I have seen-all the ice that is out there has frozen this year-and you could only go so far. You can't pass a certain point because on the other side of that [pointing to the sea ice], there is some more open water. That is where all the bears are. A lot of them [the hunters] don't get polar bears because the bears are out here where hunters can't reach them...I think eventually the bears are going to get further...I kind of find a difference... within the 30-odd years I have been doing this. Polar bears are getting further out. We are left up here hunting and they are out there.

John Lucas, Sr., May 2000

The presence or absence of ice in the harbour has also affected some cultural activities besides hunting and trapping. For example, an elder explained that each year since the 1950s, the community has held a July picnic in an area that the Inuvialuit traditionally reached by crossing the ice. The tradition of the annual picnic continued throughout the 1990s, but the Inuvialuit have had to use a boat instead of a sled to reach the site.

On the first of July, we used to picnic. We used to have to go by land. Now we go by boat... Never used to go by boat. Peter Esau

\section{Freeze-Up Season}

The majority of respondents reported that the timing of sea ice freeze-up had not changed as dramatically as that of sea ice breakup (Table 3). One elder reported that since the establishment of Sachs Harbour as a community (1956), freeze-up had typically commenced in late September when ice in the harbour became landfast. The majority of respondents suspected the freeze-up season to be only slightly delayed, but within the usual range of variation. However, respondents singled out one year, 1998-99, as a significant anomaly. Nearly all of the respondents remarked that open water remained until November that year, and community members continued boating and hunting seal from boats late into November. Respondents noted that until that year, freeze-up had always been complete by October.

Two respondents believed that the delay in freeze-up had become significant. One stated that he and his family 
TABLE 3. Sea ice seasonality: Recent changes in breakup and freeze-up timing and wind direction and strength, as reported by local experts in Sachs Harbour, Northwest Territories. ${ }^{1}$

\begin{tabular}{|c|c|c|c|c|}
\hline Respondent & Breakup & Freeze-up & Wind direction & Wind Strength (esp. during autumn and winter) \\
\hline A & Earlier and more rapidly & Later & & Stronger winds \\
\hline $\mathrm{B}$ & Earlier & Later & More north winds & Stronger winds and more windy days \\
\hline $\mathrm{C}$ & Earlier & Later & No observed change & Stronger winds and more windy days \\
\hline $\mathrm{D}$ & Earlier and more rapidly & Normal variability & No observed change & Stronger winds and more windy days \\
\hline $\mathrm{E}$ & Earlier and more rapidly & Normal variability & No observed change & Stronger winds \\
\hline $\mathrm{F}$ & Earlier and more rapidly & Later & & Stronger winds \\
\hline G & Earlier and more rapidly & Later & & \\
\hline $\mathrm{H}$ & Earlier and more rapidly & Later & & More windy days \\
\hline $\mathrm{I}$ & Earlier and more rapidly & Later & No observed change & Stronger winds \\
\hline $\mathrm{J}$ & Earlier and more rapidly & Later & No observed change & Stronger winds \\
\hline $\mathrm{K}$ & Earlier and more rapidly & Later & & More windy days \\
\hline $\mathrm{L}$ & Earlier and more rapidly & Later & No observed change & More windy days \\
\hline M & Earlier & Later & & \\
\hline $\mathrm{N}$ & Earlier & Later & No observed change & More windy days \\
\hline $\mathrm{O}$ & Earlier & Normal variability & No observed change & More windy days \\
\hline $\mathrm{P}$ & Earlier & Later & No observed change & More windy days \\
\hline
\end{tabular}

${ }^{1}$ Blank box indicates no information available.

had traditionally hunted caribou by dogsled in September and then travelled to his cabin by early October. He described September ice conditions in recent years as both "thin" and "scary," although it was not clear whether he was referring only to the 1998-99 season during this discussion. Other respondents also commented that overall, their concern about ice safety was increasing.

Freeze-up is way later. Less [multiyear ice] doesn't make the water as cold.

\section{Roger Kuptana}

\section{Observations on Other Climate Variables}

Although this survey focused specifically on observations of sea ice, the respondents also provided insightful information on the linkages they perceived between climate variables, sea ice, and the ecosystem as a whole. In this section, we note some of the observations that were shared regarding temperature, precipitation, and wind conditions.

\section{Winter Temperatures}

Many respondents agreed that average air temperatures had increased in Sachs Harbour over recent years. This warming was perceived to exist throughout the entire year, but certain seasons were identified as having a greater effect on the environment and the community. Respondents reported that, on average, the winters were warmer. The significance of warmer winter temperatures is reflected in the changes and adaptations being made to hunting and fishing, particularly regarding safety. Several respondents graphically described typical winter months in the past, when they would hear the lake "crack," the kerosene was "like milk," and the fuel, "like jelly." One of the female elders added that the fuel oil would become stiff and was difficult to use with the Primus stove.
You used to have to thaw out your ski-doo, it was so cold. Not anymore.

Larry Carpenter

\section{Spring and Summer Temperatures}

Spring was often described as a long season, when melting took place over weeks (if not months). Respondents were very clear in their assessments that spring temperatures had increased dramatically, and that the rate of melting had accelerated beyond "normal."

It is springtime that has changed really much. Fall is not the same every year-some early, some late-but fairly close. But spring is different-much different-from year to year.

Peter Esau

Long ago [it] used to be [a] long spring. Used to stay out there [at his hunting camp] for months. In the springtime... we do fishing first. After that, hunt geese; then go fishing again after that. Now we don't even go fishing after goose hunting because it melts too fast.

Geddes Wolki

Community members frequently camp inland during the spring (May-June). Ice fishing and goose hunting are the dominant activities during these trips. Within the past decade, hunters reported, these trips were adversely affected by early melt, which impeded transport and safety. The typical timing of the spring melt used to be late May; however, in recent years they had seen it occur several weeks earlier, in mid-May. Summer temperatures were described as becoming more extreme and erratic. Residents commented on both very warm and very cold conditions that were occurring during summer months. 
[The weather nowadays is] sometimes cold, but sometimes hot too... [but at the] wrong time. Way different now.

Edith Haogak

This July 1st [1999] so cold, so windy. First time I see weather like that. We were wearing parkas!

Margaret Elanik

$15^{\circ} \mathrm{C}$ on a hot day. $15^{\circ} \mathrm{C}$ is a really hot day....We didn't see temperatures like that in our younger days. We would be wearing jackets outside playing in the summer.

John Keogak

Several respondents reminded us that most of the residents' long-term knowledge of summer temperatures in Sachs Harbour was limited. Most of the previous generations had not typically spent the summers in the area before the permanent settlement was established at Sachs Harbour.

\section{Wind}

Prevailing winds were identified as northern and easterly, and wind directions varied according to season. Nearly all respondents believed that the prevailing wind directions remained unchanged, or had been modified only slightly, over the past 30 to 40 years (Table 3). Several residents described the understanding of wind direction as critical knowledge. As the winds determine snowdrift direction, one can use the drifts as navigation aids to find one's way. Knowing the wind direction would determine what strategy should be used while hunting and trapping.

When I was 12, my father said that winds always come from the east. Snowdrifts now still always [run] east-west.

Roger Kuptana

Years before, we used to have ice off and on when we'd get different kinds of wind, from the west... and from the east - they'd come from that....all the ice comes this way through that strait... and from the west, you'd get a lot of older ice, and I myself never see that much anymore because there is too much wind.

John Lucas, Sr., May 2000

All respondents active on the land reported that the magnitude and duration of high winds had increased significantly in recent years, specifically during the fall and winter (Table 3). Nearly all respondents characterized winds as being considerably more intense or frequent during the fall. The most acute example of increased intensity was the windstorm of August 1998, which resulted in damage to several homes. Strong winds have also been blamed over recent years for impeding various community activities such as herding (driving musk-oxen, Ovibos moschatus, to slaughter), boating, and hunting.
The last few years, it's almost not worth it to have a boat... because you can go out for a couple of days, and then it blows for a week. Then you go out for another couple of days, and it blows for another week. And the water gets rough really fast_-could be because there is a lot less ice.

Larry Carpenter

A couple of years ago when I was out sport hunting, [an] east wind started and it never stopped. That is why nobody got polar bears that time - too much open water. When I first came across, the weather was always kind of average, you know, you'd get wind every so often. But now, [the] past couple of years, there is a lot of east wind.

John Lucas, Sr.

Respondents were somewhat divided on identifying changes to the winter winds. Some believed that the wind strength had increased, while others contended that the strength was consistent, but that windy conditions occurred more often. In both cases, residents agreed that the winds had changed.

Wind is usually north. Lots of times long ago, wintertime [was] so cold-wind so strong — not now like that...Forty or fifty below [Celsius] and a really cold wind. Not anymore. North wind so strong, blowing so much. The wind has changed. Storms get stronger. So windy from the north in the winter.

Martha and Frank Kudlak

[Winters have been] sometimes really stormy. Wind always lasts awhile. This winter [1998-99] always storming ...sometimes the ground [has] no more snow from the wind.

Edith Haogak

Respondents often described the relationships between the presence of ice, wind fetch, wave energy, and ice safety, and their implications for the offshore hunt. Of particular interest was the relationship between ice cover and wave action. Extensive ice cover dampens waves. Hence, the greater the amount of ice, the calmer the waters will be and the safer the conditions for boating. In contrast, a reduction in sea ice cover results in greater wind fetch and more violent wave motion, leading to less safe boating conditions and a reduction in hunting and fishing opportunity. Reduction in ice cover can have other impacts as well. In one case, a resident expressed "loneliness for ice" as a result of ice disappearing entirely (Jolly et al., 2002).

\section{Rain and Thunderstorms}

Several respondents commented on their concerns regarding rain and thundershowers. During the fall, several residents told us that Sachs Harbour had traditionally been known for its dryness; however, in recent years, the amount 
of rain had increased significantly. Change in the form of precipitation was reported by many residents to be most dramatic during the fall, when expected snowfalls were being replaced with rain, thus delaying freeze-up.

While rainstorms were not new to the community, the addition of electrical storms (i.e., thunderstorms) was considered unusual to Sachs Harbour residents. Many respondents stated that they had little or no knowledge of thunderstorms before the 1990s. These events were considered rare in Sachs Harbour's settlement history.

This summer we had rain. But long ago, you would go all summer-just dry. Last five years, more rain. Used to get rain, and it would be an hour or so. Now, all day.

John Keogak

[It was] really dry here- -hardly any rain. Especially in July month, [it] used to be really warm, hardly any rain, hardly any wind. Now we have so much wind and rain, [it's] really changed.

Lena Wolki

\section{DISCUSSION}

The complex and dynamic nature of the climate system creates a serious challenge to understanding. The system itself is part of the environment, and it cannot be examined in isolation from that environment. Climate systems are regulated and influenced by a wide variety of factors and feedbacks that exist at multiple scales, both spatial (from micro to macro) and temporal (from seconds to centuries). Ocean currents, sea ice, inland water bodies, land vegetation, and atmospheric chemistry and circulation all contribute to the complicated web of energy and radiation balances that drive the climate system through energy absorption, reflection, and transmission (IPCC, 1995; Harvey, 2000). Challenges of climate change extend into the biological and human sciences. As Cruikshank (2001) asks, are there ways of generating and sharing knowledge that take into account local understandings as well as universal science?

Discussions with the Inuvialuit of Sachs Harbour often made it clear that the focus of traditional and local observations is the relationships between the elements of the climate system. These are not necessarily causal relationships, but empirical connections between elements. In contrast to much of the scientific literature, their local knowledge focused not on the variables themselves, but rather on how changes to particular variables were related to changes in other variables. This theme of "connected-ness" and "integration" was echoed many times over the course of the discussions with the respondents. Variables often went beyond that environmental dimension, entering into economic, social, and cultural repercussions of change (Figs. 2 and 3).

The observations provided by the Sachs Harbour Inuvialuit are significant, given that "wicked problems" such as climate change require place-based models and interaction between researchers and local experts. As Usher (2000:186) points out, traditional ecological knowledge "could be characterized as the knowledge claims of those who have a lifetime of observation and experience of a particular environment and as a result function very effectively in that environment, but who are untutored in the conventional scientific paradigm." Hence, Inuvialuit observations are relevant, both as firsthand experience of the changes occurring in Banks Island, and as the perspectives of a community affected culturally and economically by environmental change.

Sea ice was one of the three thematic areas of research in the Inuit Observations of Climate Change study and remained a topic of concern in interviews throughout the project. Sea ice is central to community life: people see the ice every day. Thus, even when researchers focused on wildlife, there was a great deal of discussion of sea ice. The relationships sketched in Figures 2 and 3 do not fully capture the local dynamics. The Inuvialuit focused not on average change, but on the changes in frequency and magnitude of extreme weather events, variability, and predictability (Jolly et al., 2002). The increased variability and uncertainty during the transition months (when freezeup and breakup occur) are of particular concern. Wind is considered a very important element. Many of the sea ice observations are tied directly to changes in wind frequency and strength, which is consistent with the results of indigenous observations in Alaska (Krupnik, 2002; Norton, 2002).

The ability of the Inuit to identify relationships, their knowledge about key variables acting together (e.g., sea ice and wind), and their assessment of key impacts (e.g., increased unpredictability) are significant. Observations at Sachs Harbour were remarkably consistent in providing evidence of local change in such variables as multiyear ice distribution, first-year ice thickness, and ice breakup dates (Tables 2 and 3). The knowledge and adaptations of the Inuit, reflected in their culture of hunting and fishing, enable them to perceive "change" beyond the expected year-to-year and seasonal variability. Changes observed in the 1990s were said to be without precedent and outside the normal range of variation (more detail in Jolly et al., 2002).

Inuit observations of extreme events, variability, and predictability provide a starting point for analyzing possible impacts and adaptation options, as well as for generating research questions and hypotheses for future studies. Although there is no consensus on how traditional knowledge and scientific knowledge can be used together (Wenzel, 1999; Usher, 2000), various approaches may be developed through case studies that have the potential to include both types of knowledge. In the IOCC work, we have intentionally avoided trying to synthesize or combine the two kinds of knowledge. Rather, we encourage the sharing of information between science and traditional knowledge and look for ways in which the two kinds of 
knowledge are complementary (Riedlinger and Berkes, 2001).

The use of traditional knowledge to provide a baseline against which to measure change is one kind of complementary relationship involving the two types of knowledge. A second kind involves the use of community-based monitoring to measure ice thickness or to detect various changes in sea ice that may be apparent to local residents (Krupnik, 2002). A third is the use of traditional knowledge to contribute to the process of formulating scientific hypotheses (e.g., the relationship between ice melt and thinner ringed seals). A fourth is the importance of local-level observations and expertise in detecting change in complex, multi-level systems. We expand on this last point.

In the area of remote sensing, traditional knowledge can potentially fill the gap at the local scale and provide local validation. As remote sensing relies heavily on interpretation skills, local experts may help with the interpretation. This potential area is highlighted by the remote sensing sea ice information collected over the western Arctic in 1998 by Maslanik et al. (1999). The Inuvialuit observations for the same time period reported in this study illustrate how local knowledge can confirm and expand scientific knowledge at finer scales with respect to socioeconomic variables such as boating and hunting, but also with respect to biophysical variables such as increased wind and wave action, erosion, and permafrost thaw.

A second example concerns the interpretation of sea ice changes. By analyzing 30 years of ice draft observations from nuclear submarines, Rothrock et al. (1999) found that average Arctic ice thickness had declined from over $3 \mathrm{~m}$ to less than $2 \mathrm{~m}$. Using numerical models, Zhang et al. (2000) attributed a major part of this thinning to a change in sea ice circulation that resulted in more rapid export of ice from the Arctic Ocean than in past years. That is, the ice does not stay in the basin long enough to grow to the thickness found in the past. A third view is presented by Holloway and Sou (2002), who argue that thinning is mainly due to redistribution of ice from the middle of the Arctic Ocean basin to its periphery, particularly along the Canadian Archipelago.

A problem with this latter hypothesis has been a lack of observations on the increase of ice thickness along the margins of the Archipelago. Observations and traditional knowledge provided by residents of Sachs Harbour have the potential to fill this gap. Every indication from the local experts is that ice thickness in the region has decreased, and particularly that the multiyear fraction has declined. These observations support the hypothesis of Rothrock et al. (1999) and Zhang et al. (2000) that the decrease in ice thickness in the central basin is not compensated by an increase close to shore. Additional local observations may be needed between Sachs Harbour and Alert to resolve the debate conclusively.

One drawback of using traditional knowledge alongside western science has been the challenge of translating technical terms and concepts. For example, both the science of ice and the Inuvialuit knowledge of ice have specialized terminology for ice fractures. But translation often remains inadequate because translators or interpreters rarely know both of these specialized terminologies, and a face-to-face discussion between local and scientific experts about fractures is fraught with possibilities of mistranslation. Nor is it clear to what extent the two terminologies are comparable. While the scientific terminology focuses on the causes of fractures (with respect to tidal action, upwelling, currents, and wind), the Inuvialuit terminology tends to be morphological and descriptive. For example, 'pressure ridge' was translated in Sachs Harbour as 'where you pull your sled over.' Hence, a remaining challenge is to capture the subtleties of traditional knowledge when such knowledge is documented in a language other than the original one.

\section{ACKNOWLEDGEMENTS}

This project was supported by the Walter and Duncan Gordon Foundation, the Arctic Institute of North America, the Northern Scientific Training Program, and the Social Sciences and Humanities Research Council of Canada. In-kind support was provided by the Sachs Harbour Hunters and Trappers Committee, the International Institute for Sustainable Development, the Inuvialuit Joint Secretariat, the University of Manitoba, and Fisheries and Oceans Canada. Special thanks are due to other members of the IOCC Project Team: N. Ford, G. Ashford, J. Castleden, T. Woolf, L. Rogers, B. Dickie, J. Nagy, and S. Robinson. We thank the three anonymous referees for their unusually detailed and constructive critiques and suggestions. One of the reviewers strengthened this paper by pointing out the relevance of the Sachs Harbour observations for the Rothrock/Zhang vs. Holloway and Sou debate.

\section{REFERENCES}

BERKES, F. 1999. Sacred ecology: Traditional ecological knowledge and resource management. Philadelphia: Taylor \& Francis.

BERKES, F., and JOLLY, D. 2001. Adapting to climate change: Social-ecological resilience in a Canadian western Arctic community. Conservation Ecology 5(2):18. URL: http:// Www.consecol.org/vol5/iss2/art18.

BORRE, K. 1991. Seal blood, Inuit blood, and diet: A biocultural model of physiology and cultural identity. Medical Anthropology Quarterly 5:48-62.

CONDON, R.G., COLLINGS, P., and WENZEL, G. 1995. The best part of life: Subsistence hunting, ethnicity, and economic adaptation among young adult Inuit males. Arctic 48(1):31 -46.

CRUIKSHANK, J. 2001. Glaciers and climate change: Perspectives from oral tradition. Arctic 54(4):377-393.

FAST, H., and BERKES, F. 1998. Climate change, northern subsistence and land-based economies. In: Mayer, N., and Avis, W., eds. Canada country study: Climate impacts and adaptation, Volume 8: National cross-cutting issues. Ottawa: Environment Canada. 
FENGE, T. 2001. The Inuit and climate change. Isuma, Canadian Journal of Policy Research 2(4):79-85.

FORD, N. 2000. Communicating climate change from the perspective of local people: A case study from Arctic Canada. Journal of Development Communications 1(11):93-108.

FREEMAN, M.M.R. 1984. Contemporary Inuit exploitation of the sea-ice environment. In: Sikumiut: "The people who use the sea ice." Ottawa: Canadian Arctic Resources Committee. 73-96.

FRIIBERGH WORKSHOP. 2000. Sustainability science. Statement of the Friibergh Workshop on Sustainability Science. Friibergh, Sweden. URL: http://sustsci.harvard.edu/keydocs/fulltext/ FW_statement.pdf

FURGAL, C.M., INNES, S., and KOVACS, K. 1996. Characteristics of ringed seal, Phoca hispida, subnivean structures and breeding habitat and their effects on predation. Canadian Journal of Zoology 74:858-873.

HARVEY, D.L. 2000. Global warming: The hard science. Harlow UK: Prentice Hall/Pearson Education. 335 p.

HOLLOWAY, G., and SOU, T. 2002. Has Arctic sea ice thinned? Journal of Climate 15:1691-1701.

HUNTINGTON, H.P. 1998. Observations on the utility of the semi-directive interview for documenting traditional ecological knowledge. Arctic 51(3):237-242.

- 2000. Native observations capture impacts of sea ice changes. Witness the Arctic: Chronicles of the NSF Arctic Sciences program. Fairbanks: Arctic Research Consortium of the United States. Spring 2000 (8):1. URL: http://www.arcus.org/ Witness_the_Arctic/Spring_00/Contents.html

INGOLD, T., and KURTTILA, T. 2000. Perceiving the environment in Finnish Lapland. Body \& Society 6:183-196.

IPCC (INTERGOVERNMENTAL PANEL ON CLIMATE CHANGE). 1995. The scientific assessment. Edited by Houghten, J.T., Jenkins, G.J., and Ephraums, J.J. Cambridge: Cambridge University Press.

. 1996. Climate change 1995: Impacts, adaptations and mitigation of climate change: Scientific technical analysis. Edited by Watson, R.T., Zinyowera, M.T., and Moss, R.H. Cambridge: Cambridge University Press.

—_ 1998. The regional impacts of climate change: An assessment of vulnerability. Edited by Watson, R.T., Zinyowera, M.C. and Moss, R.H. Cambridge: Cambridge University Press.

JOLLY, D., BERKES, F., CASTLEDEN, J., NICHOLS, T., and the COMMUNITY OF SACHS HARBOUR. 2002. We can't predict the weather like we used to: Inuvialuit observations of climate change, Sachs Harbour, Western Canadian Arctic. In: Krupnik, I., and Jolly, D., eds. The earth is faster now: Indigenous observations of Arctic environmental change. Fairbanks: Arctic Research Consortium of the United States. 93-125.

KRUPNIK, I. 2002. Watching ice and weather our way: Some lessons from Yupik observations on sea ice and weather on St. Lawrence Island, Alaska. In: Krupnik, I., and Jolly, D., eds. The earth is faster now: Indigenous observations of Arctic environmental change. Fairbanks: Arctic Research Consortium of the United States. 156-199.

KRUPNIK, I., and JOLLY, D., eds. 2002. The earth is faster now: Indigenous observations of Arctic environmental change. Fairbanks: Arctic Research Consortium of the United States.
LeDREW, E.F., and BARBER, D.G. 1993. Change, variability and adaptation within the marine cryosphere. University of Waterloo, Earth Observations Laboratory of the Institute for Space and Terrestrial. Science at the Department of Geography. Tech \#ISTS-EOL-TR-93-010. 104 p.

LUDWIG, D. 2001. The era of management is over. Ecosystems 4:758-764.

MASLANIK, J.A., SERREZE, M.C., and AGNEW, T. 1999. Record reduction in Western Arctic sea-ice cover in 1998: Characteristics and relationships to atmospheric circulation. Geophysical Research Letters 26(13):1905-1908.

MAXWELL, B. 1997. Responding to global climate change in the Arctic. Canada country study: Climate impacts and adaptation, Vol. 2. Ottawa: Environment Canada. URL: www.ec.gc.ca/ climate/ccs/volume2.htm

McDONALD, M., ARRAGUTAINAQ, L., and NOVALINGA,Z., eds. 1997. Voices from the Bay: Traditional ecological knowledge of Inuit and Cree in the Hudson Bay Bioregion. Ottawa: Canadian Arctic Resources Committee and Sanikiluaq, NWT.

NICHOLS, T. 1999. Development of ringed seal (Phoca hispida) habitat suitability index for the Canadian High Arctic using synthetic aperture radar. MA Thesis, Dept. of Geography, University of Manitoba, Winnipeg. $221 \mathrm{p}$.

NORTON, D.W. 2002. Coastal sea ice watch: Private confessions of a convert to indigenous knowledge. In: Krupnik, I., and Jolly, D., eds. The earth is faster now: Indigenous observations of Arctic environmental change. Fairbanks: Arctic Research Consortium of the United States. 126-155.

RIEDLINGER, D., and BERKES, F. 2001. Contributions of traditional knowledge to understanding climate change in the Canadian Arctic. Polar Record 37:315-328.

RIEWE, R. 1991. Inuit use of sea ice. Arctic and Alpine Research 23(1):3-10.

ROTHROCK, D.A., YU, Y., and MAYKUT, G.A. 1999. Thinning of the Arctic sea-ice cover. Geophysical Research Letters 26(23):3469-3472.

SMITH, T.G., and STIRLING, I. 1975. The breeding habitat of the ringed seal (Phoca hispida): The birth lair and associated structures. Canadian Journal of Zoology 53:1297-1305.

USHER. P.J. 1970. The Bankslanders: Economy and ecology of a frontier trapping community. 2 Vols. Ottawa: Department of Indian Affairs and Northern Development.

USHER, P.J. 2000. Traditional ecological knowledge in environmental assessment and management. Arctic 53(2): $183-193$.

. 2002. Inuvialuit use of the Beaufort Sea and its resources, 1960-2000. Arctic 55(Supp 1):18-28.

WENZEL, G.W. 1999. Traditional ecological knowledge and Inuit: Reflections on TEK research and ethics. Arctic 52(2):113-124. WMO(WORLD METEOROLOGICAL ORGANIZATION). 1970. WMO sea-ice nomenclature. Geneva: Secretariat of the World Meteorological Organization. No. 259. 145 p.

ZHANG, J., ROTHROCK, D., and STEELE, M. 2000. Recent changes in Arctic sea ice: The interplay between ice dynamics and thermodynamics. Journal of Climate 13:3099-3114. 